\title{
Investigating the Effects of DNA Demethylation in Chemotherapy Resistance by ChIP-on-Chip Method
}

\author{
(1) Meltem DEMIREL KARS, ${ }^{\text {(D) Gözde KOYGUN² }}$ \\ 'Program of Medicinal and Aromatic Plants, Necmettin Erbakan University Meram Vocational School, Konya-Turkey \\ ${ }^{2}$ Department of Nanotechnology and Advanced Materials, Selçuk University, Institute of Science and Technology, Konya-Turkey
}

\begin{abstract}
OBJECTIVE
This study aimed to determine the epigenetic basis of drug resistance mechanisms developed in MCF-7 breast cancer cell line that is resistant to an anticancer agent paclitaxel. Thus, we investigated the effects of the changes in DNA level on gene expression profile and proposed methods of inhibiting resistance by DNA modifications.
\end{abstract}

\section{METHODS}

We investigated the epigenetic basis of acquired drug resistance in whole genome by comparing chromosome immunoprecipitation in paclitaxel-resistant MCF-7 (MCF-7/Pac) cells and in drug-sensitive (MCF-7/S) cells. For this analysis, DNA samples from both cell lines were immunoprecipitated and labeled with $\mathrm{Cy} 3$ and $\mathrm{Cy} 5$ fluorescent dyes. Hybridization and array scanning was performed with Agilent all-Genome Microarray platform that was designed to detect DNA methylation. The obtained highthroughput information was analyzed with a bioinformatics analysis program.

\section{RESULTS}

The results showed that demethylation and epigenetic modulation of the DNA regions encoding 90 genes are significant in the development of multiple drug resistance (MDR) in breast cancer. Some of these genes, ICAM4, COX6B2, ITGB8, SLC39A4, TUBB2C, COL6A1, DAPK1, RUNX3, SLC35F3, and MAP6, are important players in the development of drug resistance and cancer stem cells.

\section{CONCLUSION}

Studies on reversing multidrug resistance can be carried out by DNA modification or methylation of target genes regions on DNA. The results presented in this study may shed light on drug development studies to make DNA modifications.

Keywords: Demethylation; epigenetics; multidrug resistance; MDR; MCF-7; paclitaxel. Copyright $\odot$ 2019, Turkish Society for Radiation Oncology

\section{Introduction}

Stable and inherited changes in gene expression without any change in DNA sequences are described as epigenetic alterations. Generally, modulation occurs on DNA or in chromatin by covalent binding and modifications. Epigenetics causes the expression of genes in genetically identical cells and organisms in different forms and show phenotypic differences.[1]

The most emphasized mechanisms is the DNA methylation, which is the hereditary change caused by the addition of methyl group to the $5^{\prime}$ end of the cytosine followed by the guanine nucleotide by the catalysis of enzyme DNA methyl transferase.[2] DNA
Dr. Meltem DEMIREL KARS

Necmettin Erbakan Üniversitesi,

Meram Meslek Yüksek Okulu,

Tıbbi ve Aromatik Bitkiler Programı, Konya-Turkey

E-mail:dmeltem@yahoo.com 
demethylation occurs by non-methylating the DNA strand after replication or during development by a replication-independent process. The impaired signaling in cancer cells may result in stable silencing of downstream targets regulated by epigenetic mechanisms.[3] Methods such as methylation-specific PCR, HELP (HpaII tiny fragment Enrichment by Ligationmediated PCR) assay can detect DNA methylation. Another approach in the determination of methylation level named "ChIP-on-chip" was developed by ChIP (chromatin immunoprecipitation) method. [4] In this method, the double-stranded DNA is separated and treated with methyl cytosine antibodies. Once the DNA has been labeled, it is hybridized with the microarray platform affixed with specific probes covering the whole human genome.

Drug resistance, which is acquired or intrinsic in the patient post-treatment or pre-treatment period, severely prevents success in cancer chemotherapy. This case is called multidrug resistance (MDR).[5] Resistance against chemotherapy prevents many anticancer drugs to show the expected effects on the patients and causes progression of the disease. Increased drug doses lead to increased side effects and limited treatment.

This study aimed to determine the effects of DNA demethylation and epigenetic bases of drug resistance mechanisms developed in MCF-7 breast cancer cell line that is resistant to anticancer agent paclitaxel (MCF-7/Pac). The resistant cell line was developed by treatment of MCF-7 breast cancer cells with paclitaxel by dose increments. Paclitaxel is an anticancer drug that inhibits cell division by interfering microtubules during mitosis. Changes in gene expression profiles of paclitaxel-resistant MCF-7 (MCF-7/Pac) cells compared to drug-sensitive (MCF-7/S) cells have been presented in previous publications.[6,7] Recently, it was reported that MCF-7/Pac cells exhibit the major features of breast cancer stem cells. [8] Therefore, determination of DNA methylation levels of MCF-7/Pac cells with respect to MCF-7/S cells will reveal the effects of DNA methylation in breast cancer stem cells. In this study, epigenetic bases of developing resistance were proposed with preliminary findings.

\section{Materials and Methods}

\section{Cell Culture Conditions}

MCF-7/S cell line sensitive to anticancer drugs and paclitaxel-resistant MCF-7/Pac cell line was used in the study.[9] RPMI 1640 containing 10\% (v/v) serum (fetal bovine serum, FBS) and $2 \mathrm{mM} \mathrm{L}$-glutamine was used as the culture medium of the cells. To prevent microbial infection, gentamycin $(1 \mathrm{mg} / \mathrm{ml})$ was added to the medium, and the cells were incubated at $37^{\circ} \mathrm{C}$, with $5 \%$ $\mathrm{CO}_{2}$ incubator. Adhesive cells were transferred into new culture medium with trypsin-EDTA when they covered $70 \%$ of the cell culture vessel. Paclitaxel-resistant cells were established by adding stepwise increasing paclitaxel in to the culture medium in two years. This cell line was used as rational model for drug resistance in breast cancer.[9]

\section{DNA Isolation and Immunoprecipitation}

The experiments were conducted according to Agilent G4170-90012_Methylation_Protocol_v.2.0 in the laboratories of Selçuk University ILTEK. The genomic DNA isolation from MCF-7/S and MCF-7/Pac cells $\left(1 \times 10^{6}\right.$ cells from each) was performed using the genomic DNA isolation kit (QIAamp DNA mini kit, QIAGEN). The quality control procedure was performed by spectrophotometric measurements (OD260nm/OD280nm, Nanodrop-Thermo) and agarose gel electrophoresis. Genomic DNA ( $5 \mu \mathrm{g}$ from each) was fragmented by ultrasonication by ultrasonicator (using micro probe, Heidolph) that was set output power to $70 \%$. The DNA fragmentation was ensured by sonicating the DNA samples for $5 \mathrm{~s}$, five cycles on ice by holding $5 \mathrm{~s}$ between each cycle intervals (to prevent heating and foaming). For immunoprecipitation procedure, Dynabeads Pan Mouse IgG magnetic beads were precipitated by magnetic stand (DynaMag-2 Magnet, Life Technologies), and the beads were bound to ChIP grade anti-5-Methyl Cytidine antibody (Abcam) by incubating in a rotator (VWR) at $4^{\circ} \mathrm{C}$ incubator. The fragmented DNA samples were then hybridized with the magnetic bead bound 5 -methylcytidine antibody in immunoprecipitation buffer (Triton X, yeast t-RNA, PBS) to let the binding of methylated DNA fragments on to the magnetic antibodies (in rotator, overnight at $4^{\circ} \mathrm{C}$ incubator). Finally, the methylated DNA fragments were sorted on magnetic stand. The methylated DNA samples and reference DNA samples (that were not immunoprecipitated) were eluted by elution in TE and SDS solution. DNA fragments were extracted through phenol-chloroform extraction method by use of MaXtract High Density tubes (QIAGEN). The aqueous phase was collected, and DNA was precipitated by adding the precipitation solution that constitutes $\mathrm{NaCl}(200 \mathrm{mM})$, glycogen $20 \mu \mathrm{g} / \mathrm{mL}$, and pure ethanol. DNA was precipitated by incubating the mixture at $4^{\circ} \mathrm{C}$ and centrifugation at $12.000 \mathrm{~g}$ for $3 \mathrm{~min}$ (Hettich). Finally, the DNA pellets were air dried. The quality of eluted methylated DNA 
and reference DNA samples of MCF-7/Pac and MCF$7 / S$ were measured by Nanodrop (Thermo).

\section{Fluorescent Labeling of DNA Samples}

Methylated and reference DNA fragments were labeled using the SureTag DNA Labeling Kit (Agilent). Briefly, DNA samples were mixed with random primers and incubated at $95^{\circ} \mathrm{C}$ for $3 \mathrm{~min}$ on heating-cooling dry block (Biosan). While DNA samples were denatured, they were labeled by Exo Klenow enzyme, dNTPs. and fluorescently labeled dUTPs (Cy-3 and Cy-5 labeled) at $37^{\circ} \mathrm{C}$ for $2 \mathrm{~h}$ in PCR machine (Biorad). After the reaction was stopped at $65^{\circ} \mathrm{C}$, labeled DNA fragments were purified by purification columns, and fluorescence binding success was determined by spectrophotometric measurements (Nanodrop, Thermo). Specific activity and labeled DNA amounts were calculated using the following formulas:

Specific activity $=$ pmol dye per $\mu \mathrm{L}$ of dye $/ \mu \mathrm{g}$ per $\mu \mathrm{L}$ DNA Yield $(\mu \mathrm{g})=$ DNA concentration $(\mathrm{ng} / \mu \mathrm{L}) \times$ sample volume $(\mu \mathrm{L}) / 1000 \mathrm{ng} / \mu \mathrm{g}$

\section{Hybridization of Labeled DNA on Arrays}

Since DNA labeling quality was good (yield $>2.5 \mu$ g and appropriate specific activity), the labeled DNA fragments were hybridized on the array platforms (Human DNA Methylation Microarray, 1×244K (HD)). Briefly, the hybridization master mix was prepared for four samples (duplicates for each cell line). Hybridization master mix constituted Human Cot-1 DNA for internal control, CGH (chromosomal genomic hybridization) blocking agent, HI-RPM hybridization buffer, and deionized formamide. Hybridization master mix (420 $\mu \mathrm{L}$ for 1-pack microarray format) was combined with Cy3- and Cy5-labeled DNA samples ( $40 \mu \mathrm{L}$ each) in one tube for each cell line. Two replicates of hybridization mixtures were prepared for MCF-7/S and MCF-7/Pac cell lines and incubated at $95^{\circ} \mathrm{C}$ for $3 \mathrm{~min}$ and $37^{\circ} \mathrm{C}$ for $30 \mathrm{~min}$ in thermal cycler (Biorad). The hybridization solution should be kept at $37^{\circ} \mathrm{C}$ until it is loaded on to the array slides. Hybridization solution was slowly dispensed on to the gasket slide carefully preventing the overflow of the solution out of the gasket chamber. Then the printed microarray slide (Agilent, Unrestricted Amadid Chip-on-Chip $1 \times 244 \mathrm{~K}$ ) was put on to the gasket slide (barcode number should be outside). Finally, the microarray slide was assembled in the slide chamber. The hybridization oven was set to $67^{\circ} \mathrm{C}$, and the chambers were placed in to the array holders in a balanced way. The hybridization pro- ceeded for $40 \mathrm{~h}$ at $20 \mathrm{rpm}$ rotation speed. Two repeats were performed for each group (MCF-7/S and MCF-7/ Pac), $(n=2)$.

\section{Washing and Scanning}

The washing equipments were washed with acetonitrile and ultrapure water previously. ChIP-on-chip wash buffer 2 was prewarmed in a coplin jar before disassembling the slide chambers $\left(37^{\circ} \mathrm{C}\right)$. The slides were disassembled in ChIP-on-chip wash buffer 1 , in to a separate coplin jar. Then the slides were put into another jar that contains wash buffer 1 for $5 \mathrm{~min}$ at room temperature (a magnetic bead was put at the basement of the jar to provide continuous stirring by magnetic stirrer). Arrays were immediately air dried, and ozone covers were put on to prevent adverse effects of the ozone on to the slides. During the whole procedure, slides should be kept by forceps. Sure Scan Microarray Scanner (Agilent), which was in the laboratory of Selçuk University ILTEK, was turned on to warm up the lasers. The G4900DA SureScan Microarray Scanner System Microarray Scan Control Software 9.1 (Agilent) was run, and Protocol Agilent HD-CGH was selected. The slides were immediately inserted into the scanner as the scanner was ready to scan the arrays. The machine recognized the barcode of the array. The green and red lasers excited the fluorescent dyes, and then photomultiplier tube detector detected the data. After scan protocol was completed, the Feature Extraction software v11.0.1.1 was operated for quality control (QC). The QC reports were generated using the grid Human DNA Methylation Microarray 244k023795-D-F-20111018.

\section{Advanced Analysis and Statistics}

The scan data of each cells were analyzed by Genomic Workbench ver6.0 (Agilent) program. Z-score algorithm was used for calculations. Gaussians were fitted to the bimodal $\log$ ratio distribution. Significant changes were determined between the groups (MCF$7 / \mathrm{S}$ and MCF-7/Pac) by Student's t-test $(\mathrm{p}<0.05)$. Finally, the significant results were listed, and the demethylation levels were calculated by calculating the fold change values and presented as the logarithm of the fold change ratios (MCF-7/Pac/MCF-7).

\section{Results}

\section{Proliferation of the Cells and Preparation of DNA Fragments}

The cell lines were cultured, and DNA isolation and QC of DNA samples were performed. Figure 1 ex- 
hibits the image of the MCF-7/Pac cells under an inverted phase contrast microscope (Leica). In Figure 2, agarose gel electrophoresis images of the genomic DNA samples and fragmented DNA smears are presented. The purity, concentration, and quality of the DNA samples isolated from the cell lines were found to be suitable for the continuation of the microarray protocol (Table 1). Table 2 presents the results of the specific activity and yield calculations of fluorescently labeled methylated and reference DNA fragments. These results showed that it was possible to continue experiments with the labeled DNA fragments of suitable concentrations. According to these results, microarray hybridization and scanning were performed.

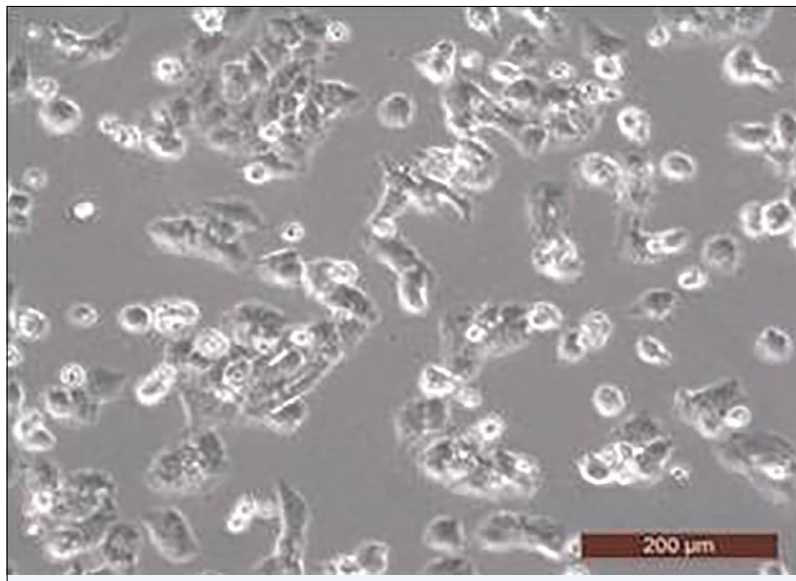

Fig. 1. Invert microscope image of MCF-7/Pac cells.
Table 1 Quality and yield of genomic DNA samples from cell lines

\begin{tabular}{lcccc} 
& $\begin{array}{c}\text { Concentration } \\
\text { ng/ } \mathbf{\mu L}\end{array}$ & Yield & \multicolumn{2}{c}{ Quality } \\
& $\mathbf{\mu g}$ & $\mathbf{2 6 0 / 2 8 0}$ & $\mathbf{2 6 0 / 2 3 0}$ \\
\hline MCF7/S1 & 143.60 & 7.90 & 1.82 & 2.23 \\
MCF7/S2 & 141.50 & 7.78 & 1.88 & 2.17 \\
MCF7/Pac1 & 158.10 & 8.69 & 1.81 & 2.04 \\
MCF7/Pac2 & 177.40 & 9.76 & 1.70 & 1.82 \\
\hline
\end{tabular}

\section{Hybridization, Washing, and Scanning Protocols}

The hybridization, washing, and scanning protocols were completed; and the QC reports were created for each arrays with the Feature Extraction program (Agilent). The results obtained for all the scanning protocols were reported as "good." The scan image and grid results obtained after scanning are presented in Figure 3. The quality analysis of the repetitive arrays for each group yielded favorable results for further analysis (Figs. 4, 5).

\section{Advanced Analysis by Genomic Workbench Program}

The raw data obtained after scanning the arrays were analyzed by Genomic Workbench ver6.0 (Agilent). The fluorescence values were analyzed, and array results for MCF-7/S and MCF-7/Pac were compared. As a result, when the drug resistance was developed, decreases in the methylation level of the gene regions on DNA (demethylation) were identified. The fold change values were calculated to reveal the demethylation levels after acquired drug resistance. The logarithms of
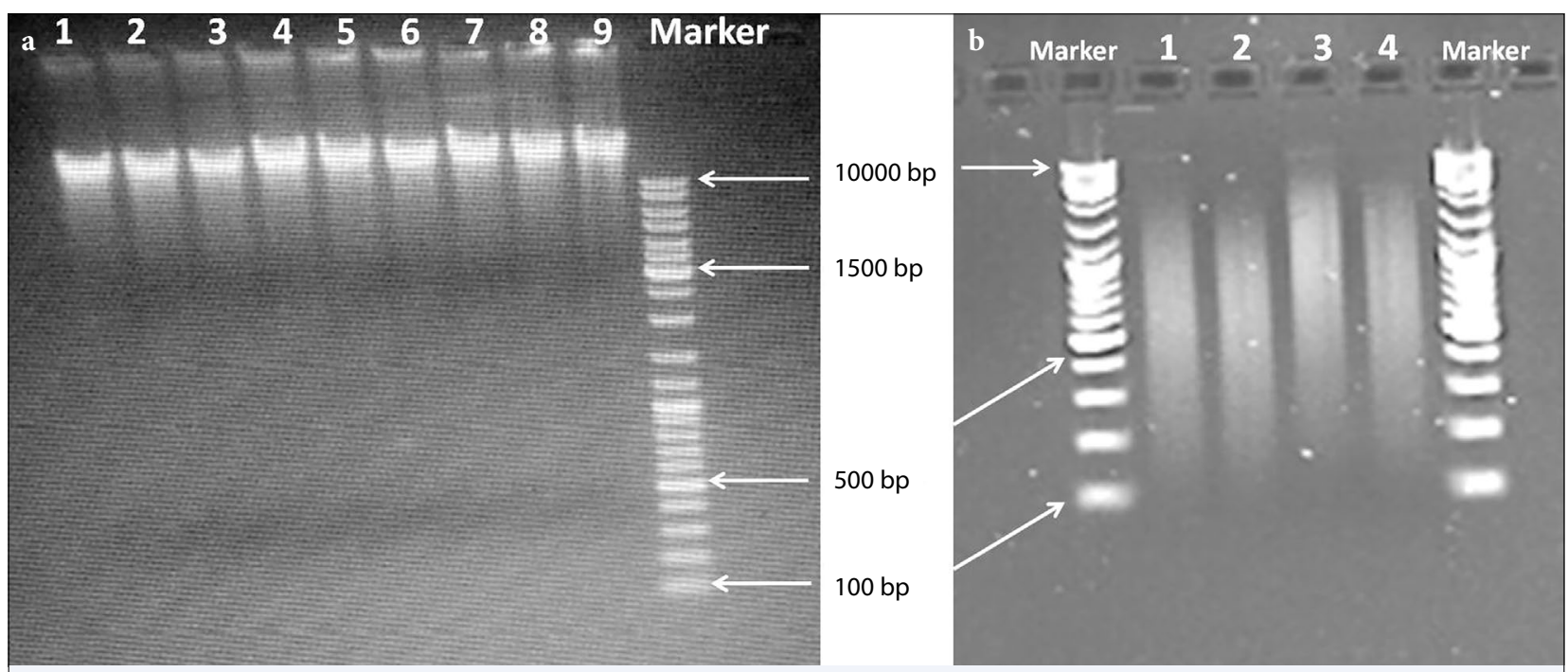

Fig. 2. (a) Agarose gel electrophoresis image of genomic DNA from cells; 1-5: MCF-7/S, 6-9: MCF-7/Pac, Marker: High range DNA ladder: $100 \mathrm{bp}-10 \mathrm{~kb}$. (b) Fragmented DNA smear from DNA samples; 1,2: MCF-7/S, 3-4: MCF-7/ Pac, Marker: High range DNA ladder: $100 \mathrm{bp}-10 \mathrm{~kb}$. 
Table 2 Cy5- and Cy3-labeled DNA concentrations and yields

Cy 5 labeled ChIP DNA

\begin{tabular}{|c|c|c|c|c|c|}
\hline \multicolumn{2}{|c|}{ Specific activity (pmol/ug) } & \multirow{2}{*}{$\begin{array}{c}\text { Yield }(\boldsymbol{\mu g}) \\
27.1\end{array}$} & \multicolumn{2}{|c|}{ Specific activity (pmol/ug) } & \multirow{2}{*}{$\frac{\text { Yield }(\boldsymbol{\mu g})}{41.1}$} \\
\hline MCF-7/S-1 & 9.80 & & Ref. MCF-7/S-1 & 11.0 & \\
\hline MCF-7/S-2 & 9.60 & 28.3 & Ref. MCF-7/S-2 & 12.0 & 43.9 \\
\hline MCF-7/Pac-1 & 7.50 & 22.5 & Ref. MCF-7/Pac-1 & 10.5 & 38.4 \\
\hline MCF-7/Pac-2 & 9.00 & 21.4 & Ref. MCF-7/Pac-2 & 9.50 & 35.4 \\
\hline
\end{tabular}

Fig. 3. Representative microarray scan photo and quality check of array corners (MCF-7/Pac).

the results were calculated and significant results were listed $(p<0.05)$ (Table 3). At the end of the analysis, we identified significant demethylation in 90 gene regions in paclitaxel-resistant breast cancer cells with respect to drug-sensitive breast cancer cell line. The demethylation levels were in range of 10.35-2.14 values. The demethylated ICAM4, COX6B2, ITGB8, SLC39A4, TUBB2C, COL6A1, DAPK1, RUNX3, SLC35F3, and MAP6 gene regions are related to cancer metastasis and cancer stem cell development.

\section{Discussion}

Cancer is a clinical problem, and it seriously affects human health and life. Although important studies have been carried out in the development of new chemotherapeutic agents, cancer still affects millions of patients worldwide. Chemotherapy-resistant breast cancer stem cells are known to make the treatment of the disease difficult. $[8,10]$ Recent studies focus on epigenetic events and MDR1 transcription changes $[11,12,13]$ due to epi- 
Table 3 Significant demethylation levels of the gene regions in MCF-7/Pac cells (MCF/Pac vs. MCF-7/S ratio of signal logarithms, $\mathrm{p}<0.05$, genes were annotated according to probe numbers.)

\begin{tabular}{|c|c|c|c|c|c|}
\hline Probe name & Gene & Demethylation level & Probe name & Gene & Demethylation level \\
\hline A_17_P17107441 & ICAM4 & 10.35 & A_17_P16147607 & EPPK1 & 2.97 \\
\hline A_17_P16897418 & IRX3 & 9.36 & A_17_P02636320 & CHST2 & 2.91 \\
\hline A_17_P11002493 & COX6B2 & 8.71 & A_17_P07432271 & TLX1 & 2.89 \\
\hline A_17_P10977774 & PNMAL1 & 6.74 & A_17_P16278514 & PTGDS & 2.88 \\
\hline A_17_P17028063 & FASN & 6.50 & A_17_P16760152 & SNRPN & 2.87 \\
\hline A_17_P11852323 & HNRNPH2 & 5.77 & A_17_P24840452 & HLA-DRB5 & 2.86 \\
\hline A_17_P15009776 & MMP23A & 5.75 & A_17_P10865025 & UHRF1 & 2.86 \\
\hline A_17_P27241394 & LPAR1 & 5.59 & A_17_P01898996 & WNT6 & 2.85 \\
\hline A_17_P15599963 & PAPSS1 & 5.27 & A_17_P01281692 & LBX2 & 2.79 \\
\hline A_17_P16269780 & SETX & 5.21 & A_17_P23515292 & NEUROG2 & 2.78 \\
\hline A_17_P15046194 & TXLNA & 5.13 & A_17_P31459414 & GPX4 & 2.71 \\
\hline A_17_P09170423 & FAM158A & 5.12 & A_17_P26552644 & REXO1L2P & 2.69 \\
\hline A_17_P04865469 & TBX18 & 5.02 & A_17_P01844528 & FZD5 & 2.69 \\
\hline A_17_P27336397 & NTNG2 & 4.95 & A_17_P16047954 & PTPRN2 & 2.67 \\
\hline A_17_P10810700 & NETO1 & 4.52 & A_17_P16468290 & CCND1 & 2.64 \\
\hline A_17_P15033838 & KLHDC7A & 4.49 & A_17_P16631901 & NUFIP1 & 2.58 \\
\hline A_17_P01379445 & POU3F3 & 4.45 & A_17_P16607147 & ULK1 & 2.56 \\
\hline A_17_P05346160 & ITGB8 & 4.44 & A_17_P15358368 & HOXD9 & 2.55 \\
\hline A_17_P09888740 & SYNGR3 & 4.28 & A_17_P30001382 & TMEM121 & 2.52 \\
\hline A_17_P16149974 & SLC39A4 & 4.21 & A_17_P17093035 & ARID3A & 2.52 \\
\hline A_17_P10485826 & CBX4 & 3.81 & A_17_P16242726 & HIATL1 & 2.51 \\
\hline A_17_P17152705 & NOSIP & 3.76 & A_17_P17094542 & DAZAP1 & 2.50 \\
\hline A_17_P16982751 & SC65 & 3.73 & A_17_P01110105 & CDC42EP3 & 2.50 \\
\hline A_17_P16047426 & PTPRN2 & 3.67 & A_17_P31464357 & MOBKL2A & 2.46 \\
\hline A_17_P03114655 & HOPX & 3.60 & A_17_P11375307 & SIM2 & 2.45 \\
\hline A_17_P10175143 & ZCCHC14 & 3.57 & A_17_P20003247 & SAMD11 & 2.42 \\
\hline A_17_P17276338 & PISD & 3.45 & A_17_P09986653 & COX6А2 & 2.37 \\
\hline A_17_P17194832 & SYS1-DBNDD2 & 3.45 & A_17_P15011388 & SKI & 2.35 \\
\hline A_17_P15587902 & CDS1 & 3.44 & A_17_P05171451 & AKAP12 & 2.31 \\
\hline A_17_P31623096 & PPFIA3 & 3.32 & A_17_P10345122 & TBKBP1 & 2.29 \\
\hline A_17_P07845095 & DRAP1 & 3.31 & A_17_P16933459 & NXN & 2.29 \\
\hline A_17_P17157815 & ZNF816A & 3.25 & A_17_P00110295 & TMEM200B & 2.28 \\
\hline A_17_P04646304 & PRRT1 & 3.20 & A_17_P09533565 & AHNAK2 & 2.28 \\
\hline A_17_P20005955 & MXRA8 & 3.20 & A_17_P00096239 & RUNX3 & 2.28 \\
\hline A_17_P31345484 & ZNF532 & 3.19 & A_17_P00870602 & SLC35F3 & 2.26 \\
\hline A_17_P12033051 & ZNF275 & 3.19 & A_17_P27342502 & ADAMTS13 & 2.25 \\
\hline A_17_P17199320 & KCNG1 & 3.13 & A_17_P11430491 & GP1BB & 2.24 \\
\hline A_17_P17234564 & SIM2 & 3.13 & A_17_P16283000 & DIP2C & 2.23 \\
\hline A_17_P16279555 & TUBB2C & 3.13 & A_17_P17191219 & PPP1R16B & 2.23 \\
\hline A_17_P17412386 & GABRE & 3.11 & A_17_P07881315 & MAP6 & 2.23 \\
\hline A_17_P16615763 & ZDHHC2O & 3.11 & A_17_P27143285 & NXNL2 & 2.22 \\
\hline A_17_P23032802 & GAK & 3.11 & A_17_P16364294 & DYDC2 & 2.20 \\
\hline A_17_P32082386 & COL6A1 & 3.02 & A_17_P17235496 & KCNJ6 & 2.19 \\
\hline A_17_P09889457 & CASKIN1 & 3.00 & A_17_P16463611 & CD248 & 2.15 \\
\hline A_17_P16236141 & DAPK1 & 3.00 & A_17_P22953020 & SOX2 & 2.14 \\
\hline
\end{tabular}

genetic alterations. It is known that methylation causes decrease in gene expression level, and demethylation may be a way to turn the gene on. Baker and El-Osta reported that epigenetic changes of ZFP (zinc finger protein-encoding gene regions) may be important in the development of drug resistance.[11] Our findings also show that different ZFP (zinc finger protein) proteins are demethylated in the development of resistance 


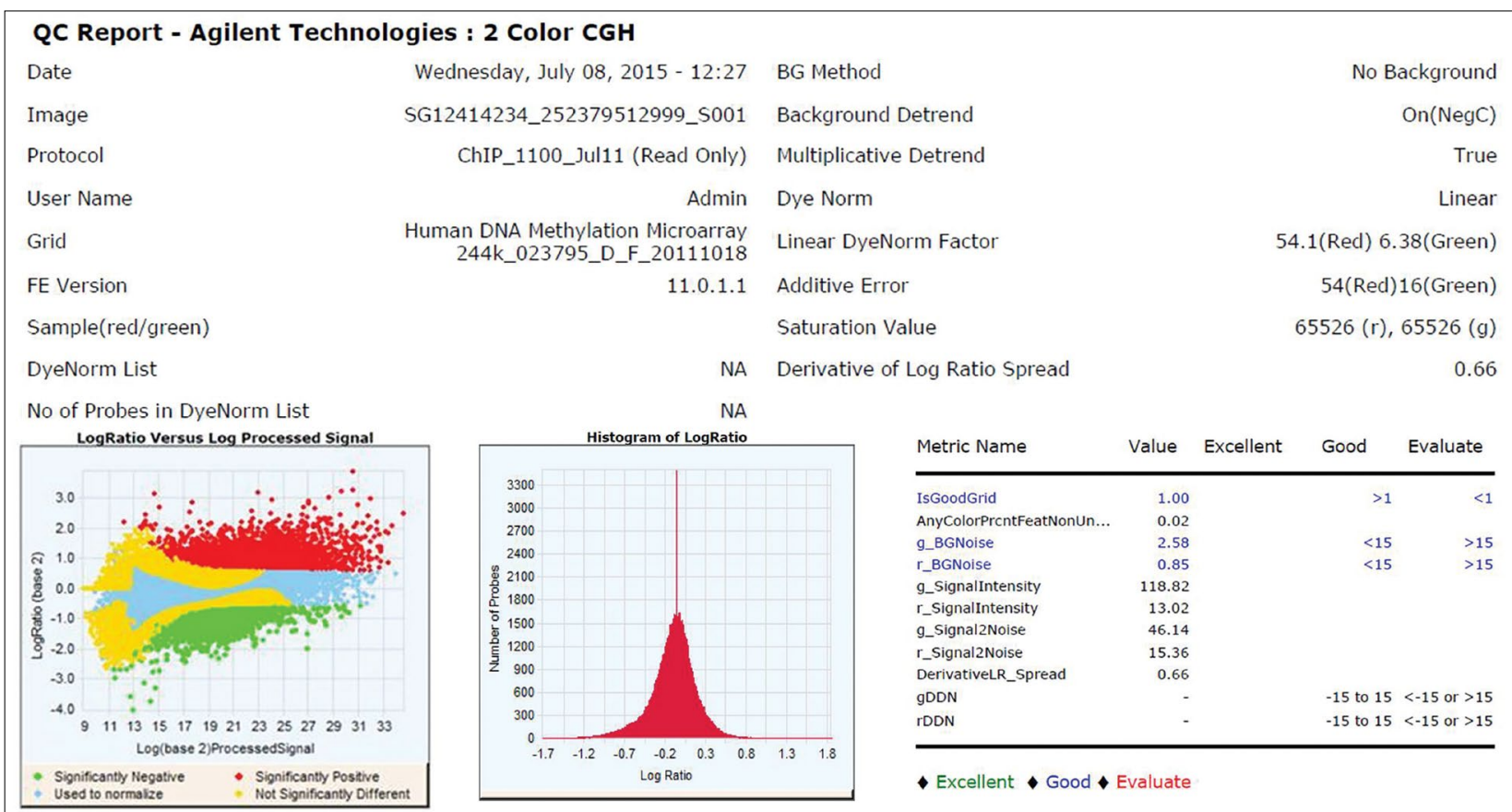

Fig. 4. Results from quality control report after Feature Extraction for an MCF-7/Pac array.

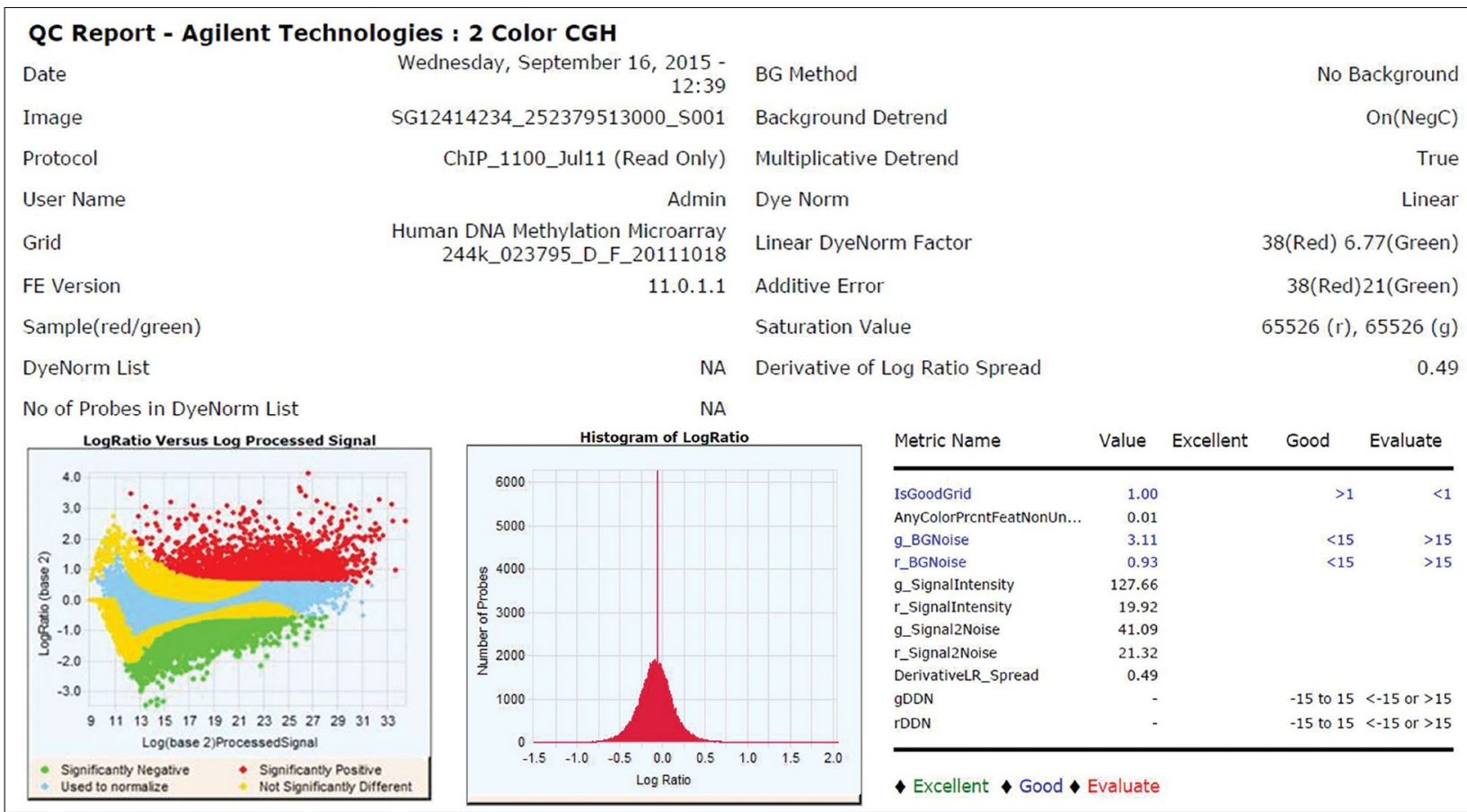

Fig. 5. Results from quality control report after Feature Extraction for an MCF-7/S array.

(Table 3). Demethylated ICAM4, COX6B2, ITGB8, It was previously claimed that intercellular adhesion SLC39A4, TUBB2C, COL6A1, DAPK1, RUNX3, protein-coding gene ICAM4 may be a breast cancer SLC35F3, and MAP6 gene regions may attract attention susceptibility gene, and genetic variants in the DNA during selection of target genes. loci was correlated with disease severity and metasta- 
sis.[14] COX6B2 encodes the subunitVIb polypeptide 2 of cytochrome-C-oxidase enzyme that functions in respiratory chain. Ayyasamy et al. demonstrated that COX6B2 was downregulated in breast cancer.[15] Here we found that COX6B2 was demethylated about 8.71 folds. Therefore, this result needs further investigation. Integrin beta- 8 is an important player of drug resistance [16] in parallel, microarray results revealed that ITG8B coding DNA was demethylated 4.4 folds in paclitaxel-resistant breast cancer cells. Solute carrier protein (SLC39A4) was proved to be a biomarker and an important protein in tumor development.[17] Here we found that SLC39A4 was demethylated about four folds in drug-resistant breast cancer cell line. Here, we can propose that SLC39A4 may be a target protein in MCF-7/Pac cell line that expresses the features of breast cancer stem cells. Tubulin beta family members are the targets of paclitaxel that inhibits mitotic division. We previously reported that expression of TUBB genes is upregulated in MCF-7/Pac cells.[18] We found here that TUBB2C gene coding DNA was demethylated about three folds. We also previously found that DAPK1 and COL6A1 genes were over-expressed in MCF-7/Pac cell line.[19] In this study, we confirmed that upregulation of those genes may be due to the demethylation process. In this study, the findings of our previous cDNA microarray analysis are confirmed by ChIP-on-chip microarray method.[20]

\section{Conclusion}

The listed 90 genes have merit to be further investigated to eliminate the uncertainty about some of them. New research questions may be asked for further research: can the clinical course of chemotherapy affect demethylation? What is the effect of an active DNA demethylase enzyme associated with the MDR1 promoter on the development of drug resistance? Answers to these questions and the results derived from this paper will allow identifying the association between demethylation and alterations in gene expression levels in drug resistance in breast cancer and for developing new methylating or demethylating therapeutic agents.

Acknowledgment: We acknowledge support from Selçuk University BAP.

Peer-review: Externally peer-reviewed.

Conflict of Interest: The authors have no conflict of interest pertaining to this manuscript.
Ethics Committee Approval: Since cell lines were used in this study, ethics committee permission is not required.

Financial Support: Selçuk University BAP project (number 14401033).

Authorship contributions: Concept - M.D.K.; Design M.D.K.; Supervision - M.D.K.; Materials - G.K.; Data collection \&/or processing - G.K.; Analysis and/or interpretation - G.K.; Literature search - M.D.K.; Writing - M.D.K.; Critical review - M.D.K.

\section{References}

1. Jones PA, Baylin SB. The epigenomics of cancer. Cell 2007;128(4):683-92.

2. Jaenisch R, Bird A. Epigenetic regulation of gene expression: how the genome integrates intrinsic and environmental signals. Nat Genet 2003;33 Suppl:245-54.

3. Dworkin AM, Huang TH, Toland AE. Epigenetic alterations in the breast: Implications for breast cancer detection, prognosis and treatment. Semin Cancer Biol 2009;19(3):165-71.

4. Gilchrist DA, Fargo DC, Adelman K. Using ChIP-chip and ChIP-seq to study the regulation of gene expression: genome-wide localization studies reveal widespread regulation of transcription elongation. Methods 2009;48(4):398-408.

5. Ueda K, Cardarelli C, Gottesman MM, Pastan I. Expression of a full-length cDNA for the human "MDR1" gene confers resistance to colchicine, doxorubicin, and vinblastine. Proc Natl Acad Sci USA 1987;84(9):3004-8.

6. Kars MD, Işeri OD, Gündüz U. A microarray based expression profiling of paclitaxel and vincristine resistant MCF-7 cells. Eur J Pharmacol 2011;657(13):4-9.

7. Işeri OD, Kars MD, Arpaci F, Atalay C, Pak I, Gündüz U. Drug resistant MCF-7 cells exhibit epithelial-mesenchymal transition gene expression pattern. Biomed Pharmacother 2011;65(1):40-5.

8. Kars MD, Yıldırım G. Determination of the target proteins in chemotherapy resistant breast cancer stem cell-like cells by protein array. Eur J Pharmacol 2019;848:23-9.

9. Kars MD, Işeri OD, Gunduz U, Molnar J. Reversal of multidrug resistance by synthetic and natural compounds in drug-resistant MCF-7 cell lines. Chemotherapy 2008;54(3):194-200.

10. Chen K, Huang YH, Chen JL. Understanding and targeting cancer stem cells: therapeutic implications and challenges. Acta Pharmacol Sin 2013;34(6):732-40.

11. Baker EK, El-Osta A. The rise of DNA methylation and the importance of chromatin on multidrug resistance in cancer. Exp Cell Res 2003;290(2):177-94. 
12. Bhattacharya SK, Ramchandani S, Cervoni N, Szyf M. A mammalian protein with specific demethylase activity for $\mathrm{mCpG}$ DNA. Nature 1999;397(6720):579-83.

13. Jovanovic J, Rønneberg JA, Tost J, Kristensen $\mathrm{V}$. The epigenetics of breast cancer. Mol Oncol 2010;4(3):242-54.

14. Rosette C, Roth RB, Oeth P, Braun A, Kammerer S, Ekblom J, et al. Role of ICAM1 in invasion of human breast cancer cells. Carcinogenesis 2005;26(5):94350.

15. Ayyasamy V, Owens KM, Desouki MM, Liang P, Bakin A, Thangaraj K, et al. Cellular model of Warburg effect identifies tumor promoting function of UCP2 in breast cancer and its suppression by genipin. PLoS One 2011;6(9):e24792.

16. Wang WW, Wang YB, Wang DQ, Lin Z, Sun RJ. Integrin beta-8 (ITGB8) silencing reverses gefitinib resis- tance of human hepatic cancer HepG2/G cell line. Int J Clin Exp Med 2015;8(2):3063-71.

17. Cui XB, Shen YY, Jin TT, Li S, Li TT, Zhang SM, et al. SLC39A6: a potential target for diagnosis and therapy of esophageal carcinoma. J Transl Med 2015 Oct 6;13:321.

18. Iseri ÖD, Kars MD, Gündüz U, Drug Resistant MCF-7 Cells have Altered Expression Levels of B-Tubulin Isotypes and Mutations in TUBB Gene. Int J Hematology Oncol 2010;20:70-83.

19. Kars MD, Molecular mechanisms of vincristine and paclitaxel resistance in MCF-7 cell line. PhD Thesis; METU: Ankara, 2008.

20. Kars MD, İşeri ÖD, Arpacı F, Gündüz U. Determination of mechanisms of multiple drug resistance in MCF-7 cell line developed against paclitaxel and vincristine by microarray analysis. Turkish Journal of Oncology (TOD) 2009;24(4):153-8. 